\title{
Rhodium(III) and ruthenium(II) complexes of redox-active, chelating N- heterocyclic carbene/thioether ligands
}

\author{
Agnès Labande, ${ }^{* a}$ Jean-Claude Daran, ${ }^{a}$ Nicholas J. Long, ${ }^{* b}$ Andrew J. P. White ${ }^{b}$ and Rinaldo Poli ${ }^{a, c}$ \\ Received (in $X X X, X X X)$ Xth $X X X X X X X X X 20 X X$, Accepted Xth XXXXXXXXX 20XX \\ ${ }_{5}$ DOI: 10.1039/b000000x
}

Dedicated to Professor Didier Astruc on the occasion of his $65^{\text {th }}$ birthday.

Half-sandwich rhodium(III) and ruthenium(II) complexes bearing a new redox-active ferrocenyl NHCthioether ligand have been prepared. The synthesis of ferrocenyl thioether-imidazolium salts $\mathbf{3 a}$ and $\mathbf{3 b}$ was carried out via intermediate $\mathbf{2}$ using an improved procedure. Rhodium(III) complex $\mathbf{4}$ and 10 ruthenium(II) complex $\mathbf{5}$ were obtained in good yields and were fully characterised by NMR spectroscopy, X-ray diffraction analysis and electrochemistry. Complex 4 shows a complex ABCD system by ${ }^{1} \mathrm{H}$ NMR, which denotes conformational rigidity due to the presence of several bulky groups. Electrochemical analysis by cyclic voltammetry reveals reversible redox behaviour about the iron centre in $\mathbf{4}$ and $\mathbf{5}$, and indicates electronic communication between iron and rhodium or ruthenium.

\section{${ }_{15}$ Introduction}

$\mathrm{N}$-Heterocyclic carbenes (NHCs) have become widely used ligands in many areas from transition metal catalysis, ${ }^{1}$ organocatalysis, ${ }^{2}$ to biochemistry and medicine. ${ }^{3}$ They are generally described as organophosphine analogues, although their $20 \sigma$-donor character is more pronounced. Unlike phosphines, they generally lead to air-stable, robust complexes which do not easily undergo ligand dissociation. However, the $\mathrm{M}-\mathrm{C}$ bond stability could be detrimental to the catalytic activity. Functionalized Nheterocyclic carbene ligands combine the robust nature of the 25 resulting metal-NHC bond with the flexibility of the secondary donor function (hemilability, stereoelectronic control on the active site) and have been successfully used in many catalytic reactions. $^{4-6}$ However, any alteration of steric or electronic properties of a ligand implies structural modifications and thus 30 more synthetic work.

Fine tuning of the electronic properties can also be achieved by introduction of redox-active moieties in the ligands. ${ }^{7}$ This has been demonstrated in the field of small molecule sensing ${ }^{8,9}$ and in catalysis. ${ }^{10}$ In the latter domain, transition metal complexes 35 containing either substitutionally inert ${ }^{11}$ or hemilabile ${ }^{12}$ redoxactive ligands have shown charge-dependent behaviour.

Our group has a strong interest in the chemistry and catalytic activity of functionalised $\mathrm{N}$-heterocyclic carbene complexes. We have shown that NHCs bearing thioether or phosphine donors 40 give very efficient and robust catalysts. ${ }^{13,14}$ The work reported here describes the preparation of redox-active NHC-thioether ligands incorporating the ubiquitous ferrocene group and the study of their coordination chemistry and electrochemical behaviour.

\section{${ }_{45}$ Results and discussion}

Synthesis
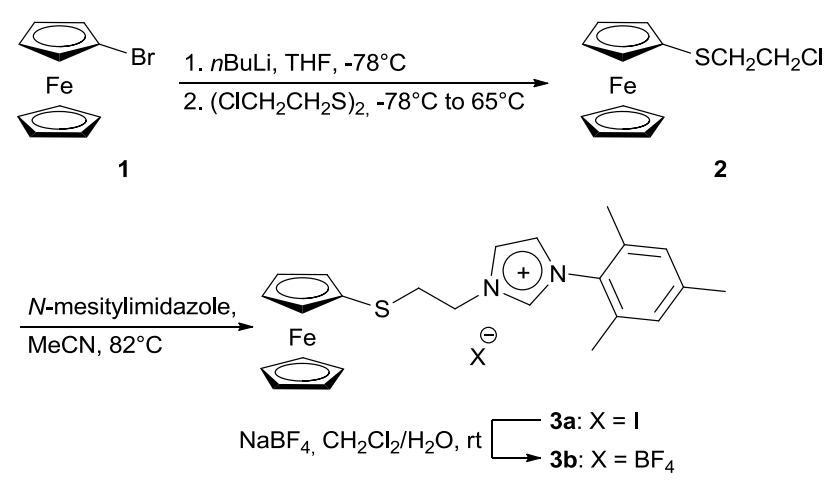

Scheme 1 Synthesis of imidazolium salts $\mathbf{3 a}$ and $\mathbf{3 b}$.

The synthesis of the imidazolium salt $\mathbf{3 b}$, i.e. the NHC-thioether 50 precursor, was achieved in three steps from bromoferrocene $\mathbf{1}$. Although the preparation of intermediate $\mathbf{2}$ and its 1,1'disubstituted analogue have been described by Mirkin et al., ${ }^{15,16}$ we decided to follow a different synthetic route. Mirkin's reported procedures involved the monolithiation of ferrocene and 55 afforded the products in very low yields, by reaction with $\mathrm{S}_{8}$ and tosylate $\mathrm{TsOCH}_{2} \mathrm{CH}_{2} \mathrm{Cl}$ (compound 2, $15 \%$ yield), ${ }^{15}$ or with disulfide $\left(\mathrm{ClCH}_{2} \mathrm{CH}_{2} \mathrm{~S}\right)_{2} \quad$ (1,1'-disubstituted analogue, $13 \%$ yield). ${ }^{16}$ We decided to start from bromoferrocene, which could be selectively and efficiently transformed into lithioferrocene. ${ }_{60}$ The reaction of the latter with bis(2-chloroethyl) disulfide was then carried out at the THF reflux temperature for $16 \mathrm{~h}$ and allowed us to dramatically improve the average yield of $\mathbf{2}$, ranging from 70 to $79 \%$. 


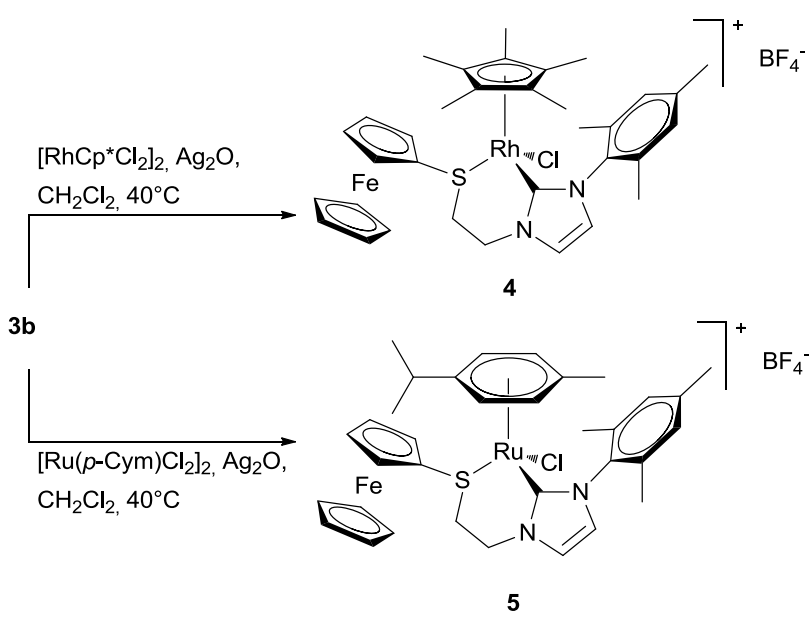

Scheme 2 Synthesis of rhodium(III) and ruthenium(II) complexes.
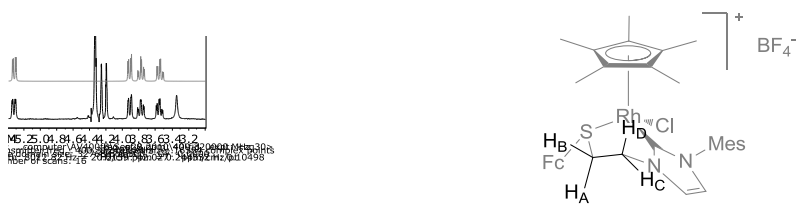

Sim.

$\begin{array}{llll}\mathrm{H}_{\mathrm{C}} & \mathrm{H}_{\mathrm{B}} & \mathrm{H}_{\mathrm{D}} & \mathrm{H}_{\mathrm{A}}\end{array}$

Exptl.

Figure 1 Assignment of the methylene protons in the ${ }^{1} \mathrm{H}$ NMR spectrum of 4: ABCD system, simulated (top) and experimental (bottom).

The intermediate imidazolium salt 3a was prepared by reaction of 2 with $\mathrm{N}$-mesitylimidazole in the presence of $\mathrm{NaI}$ to facilitate the substitution (54\% yield). This compound was characterised by ${ }^{1} \mathrm{H}$ ${ }_{10} \mathrm{NMR}$ to confirm the presence of the acidic proton, characteristic of an imidazolium salt, at $9.87 \mathrm{ppm}$. However, due to the potential hygroscopic nature of salts bearing halogen counteranions, and to the non-innocent behaviour of these anions in coordination chemistry, a metathesis with $\mathrm{NaBF}_{4}$ was carried out 15 to afford $\mathbf{3 b}$ with an overall yield of $52 \%$ from 2 . ${ }^{1} \mathrm{H}$ NMR of $\mathbf{3 b}$ showed the characteristic imidazolium proton signal at $8.78 \mathrm{ppm}$, shifted upfield relative to $\mathbf{3 a}$.

The NHC-thioether rhodium(III) and ruthenium(II) complexes $\mathbf{4}$ and $\mathbf{5}$ were then prepared by a one-pot synthesis in 20 the presence of $\mathrm{Ag}_{2} \mathrm{O}$ as transmetallating agent. ${ }^{6,17}$ The reaction was carried out with $\mathbf{3 b}$ in order to avoid a potential mixture of $\mathrm{Cl}$ and I on the Rh and Ru centres. It was conducted in the presence of excess $\mathrm{Ag}_{2} \mathrm{O}$ in dichloromethane at reflux. Forty hours were generally necessary to drive the reaction to completion and 25 consume all the imidazolium salt, as confirmed by the disappearance of the proton signal at $8.78 \mathrm{ppm}$. The synthesis of silver carbene complexes from imidazolium salts containing noncoordinating counteranions is known but usually requires harsher reaction conditions, such as high temperatures, longer reaction
30 times and the use of molecular sieves, than those generated from halide-containing imidazolium salts. ${ }^{18}$ At least one example describes the use of such silver complexes in transmetallation reactions to prepare $\mathrm{Rh}(\mathrm{I})$ complexes. ${ }^{19}$ Cationic complexes 4 and 5 were obtained in very good yields $(\mathbf{4}, 86 \% ; \mathbf{5}, 85 \%)$ as deep red 35 and orange solids respectively. Both complexes are air-stable and can be purified by column chromatography on neutral alumina.

\section{Characterisation of complexes 4 and 5}

The ${ }^{1} \mathrm{H}$ and ${ }^{13} \mathrm{C}$ NMR spectra of complex 4 confirmed the 40 coordination of both $\mathrm{NHC}$ and thioether moieties. The coordination of the carbene on rhodium was evidenced by ${ }^{13} \mathrm{C}$ NMR by a doublet at $\delta 166.3$, with a coupling constant $\mathrm{J}_{\mathrm{Rh}-\mathrm{C}}$ of 54 $\mathrm{Hz}$, typical of rhodium(III)-NHC complexes. ${ }^{13-14,20}$ All three methyl groups from the mesityl moiety are now distinct, whereas 45 the two ortho methyl groups had the same chemical shift in $\mathbf{3 b}$. This means that the rotation of the mesityl group along the C-N bond is blocked, presumably because of close contact with the Cp* ligand. The $\mathrm{CH}_{2} \mathrm{~S}$ signal shifts upfield on going from $\mathbf{3 b}(\delta$ $38.1)$ to 4 ( $\delta 35.2$ ). However, the effects of rhodium coordination 50 were best evidenced by ${ }^{1} \mathrm{H}$ NMR. All the protons of the $\mathrm{SCH}_{2} \mathrm{CH}_{2} \mathrm{Im}$ bridge become non equivalent and appear as a complex ABCD system composed of two doublets of doublets and two doublets of triplets, with the coupling pattern confirmed by a $2 \mathrm{D}-\mathrm{COSY}{ }^{1} \mathrm{H}-{ }^{1} \mathrm{H}$ experiment. This specific pattern is set by 55 the conformational rigidity imposed by the presence of several bulky groups. Indeed, the measured coupling constants are in good agreement with those predicted from the measured dihedral angles from the X-ray structure of complex $\mathbf{4}$, allowing us to assign these resonances more precisely as shown in figure 1. As ${ }_{60}$ in the ${ }^{13} \mathrm{C}$ NMR spectrum, differentiation of the two aromatic protons (slight) and ortho, ortho' methyl substituents (large) is observed in the ${ }^{1} \mathrm{H}$ NMR spectrum.

The ${ }^{1} \mathrm{H}$ NMR spectrum of the ruthenium complex $\mathbf{5}$ showed a very different pattern, as all signals were broad even at low 65 temperatures. The formation of the Ru-NHC bond, however, was confirmed by ${ }^{13} \mathrm{C}$ NMR with a signal at $\delta 164.5$, similar to other NHC ruthenium(II) complexes bearing a $p$-cymene substituent. ${ }^{6}$ Most signals were assigned by ${ }^{13} \mathrm{C}$ NMR: the $o, o^{\prime}-\mathrm{CH}_{3}$ substituents of the mesityl group were barely distinct, whereas 70 both $\mathrm{CH}\left(\mathrm{CH}_{3}\right)_{2}$ signals from the p-cymene moiety were well separated at $\delta 20.4$ and 24.8. The signals for the $\mathrm{CH}_{2} \mathrm{Im}$ carbon appeared in the expected region at $\delta 49.2$, as well as the $\mathrm{CH}_{2} \mathrm{~S}$ signal at $\delta 33.7$. The ${ }^{13} \mathrm{C}$ NMR signals for ferrocene were situated in the expected region between $\delta 72$ and 68 but appeared very 75 broad. The ${ }^{1} \mathrm{H}$ NMR spectrum analysis was more complicated. The proton signals of the mesityl and $p$-cymene groups were assigned without ambiguity and all six methyl groups were differentiated. However, only one proton of $\mathrm{CH}_{2} \mathrm{Im}$ could be assigned at $\delta 4.86$. The other one was not found even with the 80 help of $2 \mathrm{D}{ }^{1} \mathrm{H}-{ }^{1} \mathrm{H}$ or ${ }^{1} \mathrm{H}-{ }^{13} \mathrm{C}$ correlation experiments, as were the $\mathrm{CH}_{2} \mathrm{~S}$ protons. Those might be overlapping with other signals, or broadened out. However, the mass spectrometry and X-ray diffraction analyses confirmed the expected structure for $\mathbf{5}$.

Complexes $\mathbf{4}$ and $\mathbf{5}$ were analysed by single crystal X-ray 85 diffraction. Both structures consist of isolated cations and anions with no short interionic contacts. In compound $\mathbf{4}$, there is one $\mathrm{CH}_{2} \mathrm{Cl}_{2}$ solvent molecule. Comparison of selected bond distances, 
angles and torsion angles are given in Table 1 (also in Supporting Information) and ORTEP views for each complex are shown in Figure 2. The structures are closely related, they both contain the same thioether-NHC ligand chelating the metal to form a six-
5 membered ring and a $\mathrm{Cl}$ atom but differ by the $\pi$-ligand: $\mathrm{Cp}^{*}$ for the rhodium complex and $p$-cymene for the ruthenium compound. The $\mathrm{Cp}^{*}$ is in $\eta^{5}$-coordination mode whereas the $p$-cymene is in $\eta^{6}$-coordination. Considering these two ligands as a single
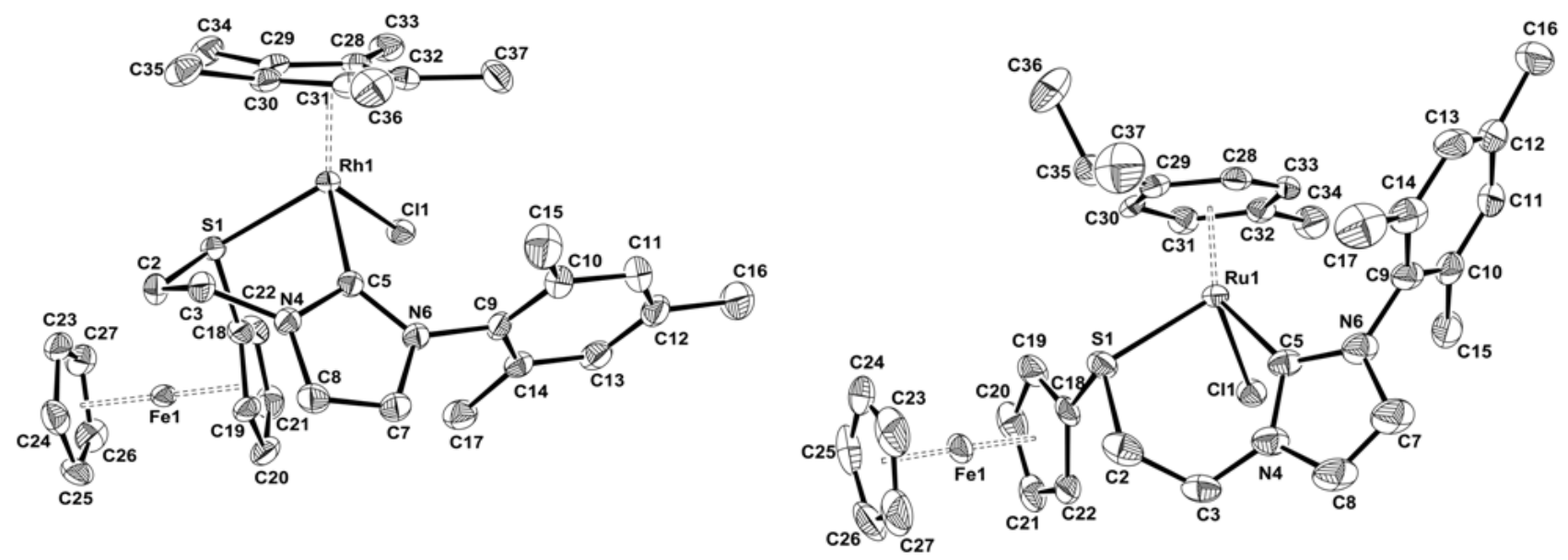

Figure 2 Molecular views of compounds 4 (left) and 5 (right) with the atom-labelling scheme. Displacement ellipsoids are drawn at the $50 \%$ probability 10 level. $\mathrm{H}$ atoms have been omitted for clarity.

Table 1 Selected bond lengths $(\AA)$, angles $\left(^{\circ}\right)$ and torsion angle $\left(^{\circ}\right)$ for complexes $\mathbf{4}$ and $\mathbf{5}$

\begin{tabular}{ccc}
\hline & $\mathbf{4}(\mathrm{M}=\mathrm{Rh})$ & $\mathbf{5}(\mathrm{M}=\mathrm{Ru})$ \\
\hline M1-Cg1 & $1.8334(8)$ & $1.7460(15)$ \\
M1-Cl1 & $2.3785(4)$ & $2.3944(9)$ \\
M1-S1 & $2.3622(4)$ & $2.3501(10)$ \\
M1-C5 & $2.0550(17)$ & $2.091(4)$ \\
S1-C2 & $1.822(2)$ & $1.798(4)$ \\
S1-C18 & $1.7631(9)$ & $1.774(4)$ \\
C2-C3 & $1.524(3)$ & $1.510(6)$ \\
C3-N4 & $1.459(2)$ & $1.454(6)$ \\
C7-C8 & $1.341(3)$ & $1.331(7)$ \\
& & \\
Cg1-M1-C11 & $119.92(3)$ & $125.09(6)$ \\
Cg1-M1-S1 & $123.28(3)$ & $119.72(6)$ \\
Cg1-M1-C5 & $133.87(6)$ & $134.56(12)$ \\
C11-M1-S1 & $90.407(16)$ & $91.66(4)$ \\
C11-M1-C5 & $91.64(5)$ & $81.79(11)$ \\
S1-M1-C5 & $85.68(5)$ & $91.54(12)$ \\
& & \\
S1-C2-C3-N4 & $-50.5(2)$ & $-73.3(4)$ \\
\hline
\end{tabular}

Cg1 defines the centroid of the cycle above the metal.

15 coordination site, the overall coordination geometry about each metal centre is pseudo-tetrahedral or typical piano-stool geometry. However, in the case of ruthenium $p$-cymene complexes, it is usual to describe them as pseudo-octahedral, the $\eta^{6}$-ligand occupying one face of the octahedron. The other three 20 sites in complex $\mathbf{5}$ are occupied by the S1, C5 and Cl1 atoms.

Whatever the description of the coordination about the metal, the M1-S1, M1-C5 and M1-Cl1 bond lengths are comparable for the two compounds (Table 1). The only marked differences concern the angles. Indeed, the $\mathrm{Cg} 1-\mathrm{M} 1-\mathrm{Cl} 1$ angle is much larger 25 for the ruthenium complex 5, 125.09(6) ${ }^{\circ}$, than for the rhodium one $4,119.92(3)^{\circ}$. Such a difference may be explained by the bulkier $p$-cymene ligand with the substituted methyl roughly above the $\mathrm{Cl}$ position. Another difference is the larger value observed for the S1-Ru1-C5 angle - 91.54(12) ${ }^{\circ}$ compared to $3085.68(5)^{\circ}$ for $\mathrm{S} 1-\mathrm{Rh} 1-\mathrm{C} 5$. This is certainly related to the difference in conformation for the chelate ring, which is boat for the rhodium complex and half-chair for the ruthenium one. The difference is reflected in the S1-C2-C3-N4 torsion angles, $50.5(2)^{\circ}$ for 4 and $-73.3(4)^{\circ}$ for 5 . This difference in 35 conformation results in a different dihedral angle between the coordinated $\mathrm{Cp}$ of the ferrocene moiety and the imidazol-2ylidene ring: $61.03(12)^{\circ}$ for $\mathbf{4}$ and $39.9\left(2^{\circ}\right)$ for $\mathbf{5}$.

The Rh1-C5 distance of 2.0550(17) $\AA$ compares well with related NHC-Cp* rhodium complexes. $^{20-21}$ The Ru1-C5 distance 40 of 2.091(4) $\AA$ is slightly long but in the range of other NHCruthenium complexes, which are found between 2.028(4) and 2.0828(14) $\AA^{6,21}$ The average M1-Cl1 and M1-S1 distances are in agreement with other structurally characterised cationic $\eta^{5}-\mathrm{Cp}^{*}$ rhodium or $\eta^{6}-p$-cymene ruthenium complexes reported in the ${ }_{45}$ Cambridge Structural Database. ${ }^{22}$ Both ferrocene moieties have eclipsed conformation and usual geometry. ${ }^{22}$

\section{Electrochemistry}

The imidazolium salts $\mathbf{3 a}, \mathbf{3 b}$ and complexes $\mathbf{4}$ and $\mathbf{5}$ were analysed by cyclic voltammetry in dichloromethane. The 50 voltammogram of $\mathbf{3 a}$ exhibited several waves, as the iodide anion itself is redox-active. ${ }^{23}$ The redox potential for the ferrocene group is observed at $E_{1 / 2}=+0.64 \mathrm{~V} / \mathrm{SCE}$ with a chemically reversible behaviour $\left(\Delta E_{\mathrm{p}}\right.$ is $120 \mathrm{mV}$, however, and may indicate slow electron transfer at the surface of the electrode). The 55 voltammogram of $\mathbf{3 b}$ only shows the chemically reversible wave for the ferrocene unit at $+0.64 \mathrm{~V} / \mathrm{SCE}\left(\Delta E_{\mathrm{p}}=111 \mathrm{mV}\right)$, see Figure $3 .^{24}$

The $\mathrm{Fe}^{\mathrm{II}} / \mathrm{Fe}^{\mathrm{III}}$ couple in the rhodium complex 4 (Figure 4) is anodically shifted compared to the imidazolium salts with a ${ }_{60}$ potential of $+0.77 \mathrm{~V} / \mathrm{SCE}\left(\Delta E_{\mathrm{p}}=111 \mathrm{mV}\right)$ and exhibits 
chemically reversible behaviour. The anodic shift signals a weak electron-withdrawing effect of coordination to rhodium and indicates electronic communication between iron and rhodium through the sulfur atom. The cyclic voltammogram of the 5 ruthenium complex 5 also presents a chemically reversible redox wave at $+0.76 \mathrm{~V} / \mathrm{SCE}\left(\Delta E_{\mathrm{p}}=84 \mathrm{mV}\right)$ attributed to the $\mathrm{Fe}^{\mathrm{II}} / \mathrm{Fe}^{\mathrm{III}}$ couple, see Figure 4. A very weak oxidation wave was detected at approximately $+1.7 \mathrm{~V} / \mathrm{SCE}$ and was tentatively assigned to the $\mathrm{Ru}^{\mathrm{II}} / \mathrm{Ru}^{\mathrm{III}}$ couple. Analysis by square-wave voltammetry more 10 clearly revealed this wave at $+1.68 \mathrm{~V} / \mathrm{SCE}$ (see Supporting Information), however it is far less intense than the $\mathrm{Fe}^{\mathrm{II}} / \mathrm{Fe}^{\mathrm{III}}$ wave. A similar $\mathrm{Ru}(\mathrm{II}) \mathrm{p}$-cymene complex, bearing a chelating NHC-thioether ligand with methyl in place of ferrocenyl, exhibits $\mathrm{a} \mathrm{Ru}^{\mathrm{II}} / \mathrm{Ru}^{\mathrm{III}}$ redox wave at $+1.55 \mathrm{~V} / \mathrm{SCE}{ }^{6}$ The anodic shift of the 15 oxidation potential for the $\mathrm{Ru}^{\mathrm{II}} / \mathrm{Ru}^{\mathrm{III}}$ couple is attributed to the stronger electron-withdrawing effect of the oxidised form of ferrocene compared to $\mathrm{CH}_{3}$. The aspect of the voltammogram also suggests that the iron oxidation has an effect on the redox behaviour of ruthenium, whose oxidation becomes irreversible. ${ }^{25}$

20 The electrochemical behaviour of both complexes suggests that it should be possible to alter selectively and reversibly the oxidation state of iron by a careful choice of oxidizing and reducing agents. $^{23}$

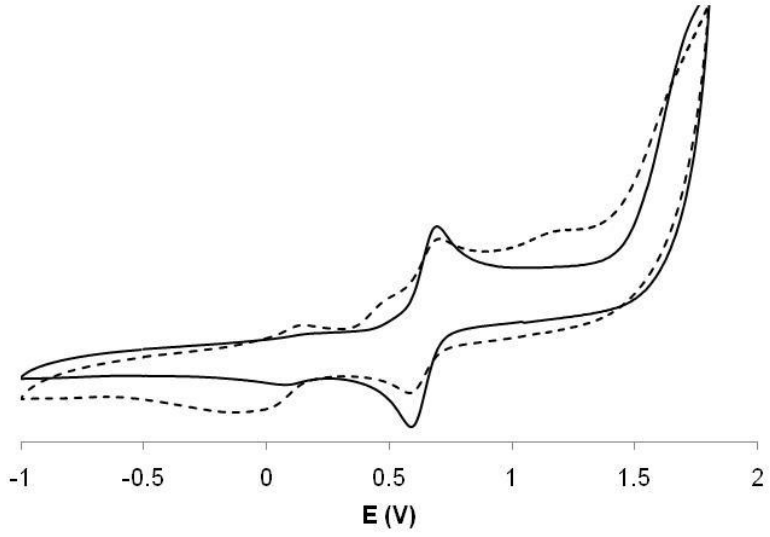

Figure 3 Cyclic voltammograms of imidazolium salts $\mathbf{3 a}$ (dashed) and $\mathbf{3 b}$ (plain), $1 \mathrm{mM}$ in $\mathrm{CH}_{2} \mathrm{Cl}_{2}$ at a scan rate of $0.2 \mathrm{~V} / \mathrm{s}$.

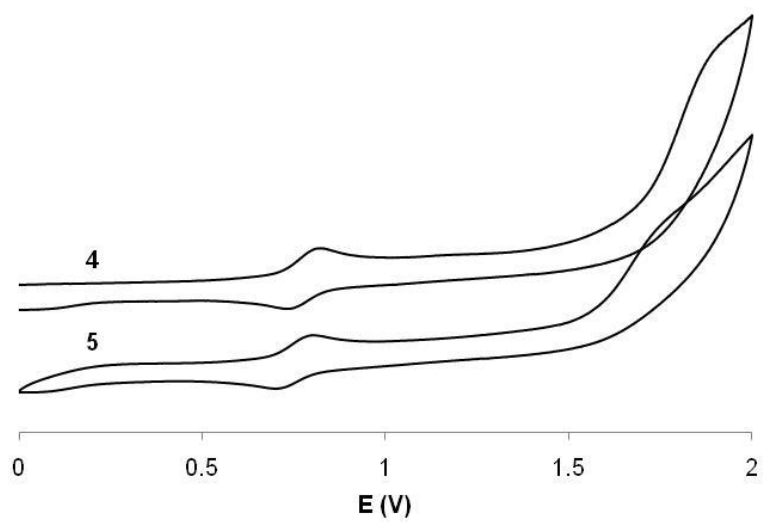

Figure 4 Cyclic voltammogram of complexes 4 and 5, $1 \mathrm{mM}$ in $\mathrm{CH}_{2} \mathrm{Cl}_{2}$ at a scan rate of $0.2 \mathrm{~V} / \mathrm{s}$.

\section{Conclusions}

Two half-sandwich rhodium(III) and ruthenium(II) complexes bearing a new redox-active NHC-thioether ligand have been prepared and their electrochemical properties investigated. Cyclic 35 voltammetry experiments have shown that the ferrocenyl unit can be oxidised and reduced reversibly. The catalytic properties of these complexes and the influence of the redox state of iron on the catalytic performances are under investigation and the results will be reported in due course.

\section{${ }_{40}$ Acknowledgements}

The authors thank the CNRS, the Agence Nationale de la Recherche for a grant to A.L. (ANR-07-JCJC-0041) and the Institut National Polytechnique for a grant to R.P. and A.L. (Soutien à la Mobilité Internationale).

\section{${ }_{45}$ Experimental}

\section{General Procedures}

All reactions were performed under an atmosphere of dry nitrogen or argon using standard Schlenk techniques, unless otherwise stated. Solvents were dried and distilled by standard 50 techniques prior to use. NMR spectra were recorded on Bruker AV300, AV400 or AV500 spectrometers. NMR chemical shifts were determined by reference to the residual ${ }^{1} \mathrm{H}$ or ${ }^{13} \mathrm{C}$ solvent peaks in the deuterated solvents. The NMR simulation experiment was done with SpinWorks 3. Electrospray (ES) mass 55 spectra were recorded either at Imperial College on a Micromass LCT Premier spectrometer or at the Université Paul Sabatier by the Service Commun de Spectrométrie de Masse on a MS/MS API-365 (Perkin Elmer Sciex). Elemental analyses were performed either by Mr. Stephen Boyer at London Metropolitan ${ }_{60}$ University or by the Service d'Analyses du Laboratoire de Chimie de Coordination in Toulouse. Cyclic voltammetry (CV) and square-wave voltammetry (SQW) experiments were carried out with a PGSTAT-302N potentiostat (Metrohm) at $20^{\circ} \mathrm{C}$ using a Pt disk working electrode, a Pt wire counter electrode and a 65 saturated calomel reference electrode (SCE); a $0.1 \mathrm{M} n-\mathrm{Bu}_{4} \mathrm{BF}_{4}$ solution was used as the supporting electrolyte. All electrochemical data are referenced versus SCE. Bromoferrocene 1 was prepared by a previously described procedure. ${ }^{26}$

\section{Syntheses}

70 2-Chloroethylthioferrocene (2). ${ }^{15-16}$ A solution of bromoferrocene $(300 \mathrm{mg}, 1.13 \mathrm{mmol}$, containing $92 \% \mathrm{FcBr}, 7 \%$ ferrocene and $\left.1 \% \mathrm{FcBr}_{2}\right)$ in THF $(15 \mathrm{~mL})$ was cooled to $-78^{\circ} \mathrm{C} . n$ $\operatorname{BuLi}(800 \mu \mathrm{L}, 1.24 \mathrm{mmol})$ was added dropwise and the solution was stirred for $30 \mathrm{~min}$ at $-78^{\circ} \mathrm{C}$. A solution of 275 chloroethyldisulfide $(260 \mathrm{mg}, 1.36 \mathrm{mmol})$ in THF $(5 \mathrm{~mL})$ was added dropwise and the mixture was allowed to warm to room temperature for $2 \mathrm{~h}$. The mixture was then heated at $65^{\circ} \mathrm{C}$ for 16 h. It was allowed to cool to room temperature and $\mathrm{H}_{2} \mathrm{O}(10 \mathrm{~mL})$ was added. The phases were separated and the aqueous phase was 80 extracted with $\mathrm{Et}_{2} \mathrm{O}$. The organic phases were combined, washed with $\mathrm{H}_{2} \mathrm{O}$, dried $\left(\mathrm{MgSO}_{4}\right)$, filtered and concentrated in vacuo. The yellow liquid was purified by column chromatography on neutral alumina (grade I). The first band contained mainly ferrocene and the desired product was obtained as a yellow liquid in the second 85 band (250 mg, 79\%). ${ }^{1} \mathrm{H} \mathrm{NMR}\left(400 \mathrm{MHz}, \mathrm{CDCl}_{3}\right) \delta 4.34\left(\mathrm{t}, \mathrm{J}_{\mathrm{HH}}\right.$ 
$=1.8 \mathrm{~Hz}, 2 \mathrm{H}, \mathrm{Cp}), 4.26\left(\mathrm{t}, \mathrm{J}_{\mathrm{HH}}=1.8 \mathrm{~Hz}, 2 \mathrm{H}, \mathrm{Cp}\right), 4.24(\mathrm{~s}, 5 \mathrm{H}$, Cp'), 3.60-3.56 (m, 2H, $\left.\mathrm{CH}_{2} \mathrm{Cl}\right), 2.89-2.85\left(\mathrm{~m}, 2 \mathrm{H}, \mathrm{CH}_{2} \mathrm{~S}\right)$.

\section{1-( $\beta$-(ferrocenylthio)-ethyl)-3-(2,4,6-trimethylphenyl)}

imidazolium iodide (3a). A mixture of $2(250 \mathrm{mg}, 0.89 \mathrm{mmol})$, $5 \mathrm{~N}$-mesitylimidazole (249 mg, $1.34 \mathrm{mmol})$ and $\mathrm{NaI}(267 \mathrm{mg}, 1.78$ mmol) in degassed acetonitrile $(20 \mathrm{~mL})$ was heated at $80^{\circ} \mathrm{C}$ for $16 \mathrm{~h}$. After cooling to room temperature, the solvent was evaporated and the residue taken up into $\mathrm{CH}_{2} \mathrm{Cl}_{2}$. The solution was filtered through Celite and the solvent evaporated to a 10 minimum. Excess $\mathrm{Et}_{2} \mathrm{O}$ was added and the yellow precipitate was filtered on Celite, rinsed with $\mathrm{Et}_{2} \mathrm{O}$ then taken up into $\mathrm{CH}_{2} \mathrm{Cl}_{2}$. Evaporation of the solvent afforded 3a as a yellow solid $(268 \mathrm{mg}$, $54 \%$ ). ${ }^{1} \mathrm{H}$ NMR (400 MHz, $\left.\mathrm{CDCl}_{3}\right) \delta 9.87\left(\mathrm{t}, \mathrm{J}_{\mathrm{HH}}=1.5 \mathrm{~Hz}, 1 \mathrm{H}\right.$, $\mathrm{NCHN}), 7.85\left(\mathrm{t}, \mathrm{J}_{\mathrm{HH}}=1.7 \mathrm{~Hz}, 1 \mathrm{H}, H \mathrm{C}=\mathrm{CH} \mathrm{Im}{ }^{+}\right), 7.20\left(\mathrm{t}, \mathrm{J}_{\mathrm{HH}}=\right.$ $151.8 \mathrm{~Hz}, 1 \mathrm{H}, \mathrm{HC}=\mathrm{CH} \mathrm{Im}^{+}$), 7.05 (s, 2H, CH Mes), 4.79 (pseudo t, $\left.\mathrm{J}_{\mathrm{HH}}=5.9 \mathrm{~Hz}, 2 \mathrm{H}, \mathrm{CH}_{2} \mathrm{Im}^{+}\right), 4.34\left(\mathrm{~d}, \mathrm{~J}_{\mathrm{HH}}=1.8 \mathrm{~Hz}, 2 \mathrm{H}, \mathrm{Cp}\right), 4.27$ $\left(\mathrm{d}, \mathrm{J}_{\mathrm{HH}}=1.8 \mathrm{~Hz}, 2 \mathrm{H}, \mathrm{Cp}\right), 4.20$ (s, 5H, Cp'), 3.21 (pseudo t, $\mathrm{J}_{\mathrm{HH}}=$ $5.9 \mathrm{~Hz}, 2 \mathrm{H}, \mathrm{CH}_{2} \mathrm{~S}$ ), 2.38 (s, $3 \mathrm{H}, p-\mathrm{CH}_{3} \mathrm{Mes}$ ), 2.15 (s, $6 \mathrm{H}, o-\mathrm{CH}_{3}$ Mes).

\section{1-( $\beta$-(ferrocenylthio)-ethyl)-3-(2,4,6-trimethylphenyl)}

imidazolium tetrafluoroborate (3b). Compound $\mathbf{2}(224 \mathrm{mg})$ was treated as described previously and crude 3a was dissolved in degassed $\mathrm{CH}_{2} \mathrm{Cl}_{2}(15 \mathrm{~mL})$. A solution of $\mathrm{NaBF}_{4}(438 \mathrm{mg}, 3.99$ mmol) in degassed $\mathrm{H}_{2} \mathrm{O}(10 \mathrm{~mL})$ was added and the mixture was 25 stirred vigorously for $16 \mathrm{~h}$. The two phases were separated and the aqueous phase was extracted with $\mathrm{CH}_{2} \mathrm{Cl}_{2}$. The combined organic phases were washed with $\mathrm{H}_{2} \mathrm{O}$, dried $\left(\mathrm{Na}_{2} \mathrm{SO}_{4}\right)$, filtered and concentrated in vacuo to ca. $2 \mathrm{~mL}$. Excess $\mathrm{Et}_{2} \mathrm{O}$ was added and the yellow precipitate was filtered through Celite, rinsed with

${ }_{30} \mathrm{Et}_{2} \mathrm{O}$ then taken up into $\mathrm{CH}_{2} \mathrm{Cl}_{2}$. Evaporation of the solvent afforded $\mathbf{3 b}$ as a yellow solid $(216 \mathrm{mg}, 52 \%)$. ${ }^{1} \mathrm{H}$ NMR (400 $\left.\mathrm{MHz}, \mathrm{CDCl}_{3}\right) \delta 8.78(\mathrm{~s}, 1 \mathrm{H}, \mathrm{NCHN}), 7.73\left(\mathrm{~s}, 1 \mathrm{H}, H \mathrm{C}=\mathrm{CH} \mathrm{Im}{ }^{+}\right)$, $7.23\left(\mathrm{~s}, 1 \mathrm{H}, \mathrm{HC}=\mathrm{CH} \mathrm{Im}^{+}\right), 7.03(\mathrm{~s}, 2 \mathrm{H}, \mathrm{CH} \mathrm{Mes}), 4.48\left(\mathrm{t}, \mathrm{J}_{\mathrm{HH}}=\right.$ $\left.5.9 \mathrm{~Hz}, 2 \mathrm{H}, \mathrm{CH}_{2} \mathrm{Im}^{+}\right), 4.33\left(\mathrm{~d}, \mathrm{~J}_{\mathrm{HH}}=1.7 \mathrm{~Hz}, 2 \mathrm{H}, \mathrm{Cp}\right), 4.25\left(\mathrm{~d}, \mathrm{~J}_{\mathrm{HH}}\right.$ $\left.{ }_{35}=1.7 \mathrm{~Hz}, 2 \mathrm{H}, \mathrm{Cp}\right), 4.18\left(\mathrm{~s}, 5 \mathrm{H}, \mathrm{Cp}\right.$ '), $3.07\left(\mathrm{t}, \mathrm{J}_{\mathrm{HH}}=5.9 \mathrm{~Hz}, 2 \mathrm{H}\right.$, $\mathrm{CH}_{2} \mathrm{~S}$ ), 2.36 (s, 3H, $\left.p-\mathrm{CH}_{3} \mathrm{Mes}\right), 2.08$ (s, 6H, o-CH $\left.\mathrm{CH}_{3} \mathrm{Mes}\right) .{ }^{13} \mathrm{C}$ NMR $\left(100 \mathrm{~Hz}, \mathrm{CDCl}_{3}\right) \delta 141.36\left(C_{\text {quat }} \mathrm{Mes}\right), 136.94(\mathrm{NCHN})$, $134.49\left(2 \times C_{\text {quat }}\right.$ Mes), 130.64 ( $C_{\text {quat }}$ Mes $), 129.83$ (2xCH Mes), $123.70\left(C=\mathrm{C} \mathrm{Im}^{+}\right), 123.52\left(\mathrm{C}=C \mathrm{Im}^{+}\right), 73.94(2 \times C H \mathrm{Cp}), 69.99$ 40 (2xCH Cp), 69.61 (5xCH Cp'), $49.29\left(\mathrm{CH}_{2}-\mathrm{Im}^{+}\right), 38.07\left(\mathrm{CH}_{2} \mathrm{~S}\right)$, $21.14\left(p-\mathrm{CH}_{3} \mathrm{Mes}\right), 17.32\left(2 \mathrm{x} o-\mathrm{CH}_{3} \mathrm{Mes}\right) . C_{\text {quat }} \mathrm{Cp}$ not found. ${ }^{19} \mathrm{~F}$ NMR $\left(282 \mathrm{MHz}, \mathrm{CDCl}_{3}\right) \delta-151.6\left(\mathrm{BF}_{4}^{-}\right)$. MS $\left(\mathrm{ESI}^{+}\right) \mathrm{m} / \mathrm{z}, 431$ $\left(\mathrm{M}^{+}, 100 \%\right)$. Elem. Anal. $\mathrm{C}_{24} \mathrm{H}_{27} \mathrm{BF}_{4} \mathrm{FeN}_{2} \mathrm{~S}$ (518.03): calc. C, $55.60 ; \mathrm{H}, 5.25 ; \mathrm{N}, 5.41$; found $\mathrm{C}, 55.48 ; \mathrm{H}, 5.28 ; \mathrm{N}, 5.37$.

${ }_{45}$ Rhodium complex (4). Imidazolium salt 3b $(56.4 \mathrm{mg}, 0.109$ $\mathrm{mmol}),\left[\mathrm{RhCp}^{*} \mathrm{Cl}_{2}\right]_{2}(59.3 \mathrm{mg}, 0.096 \mathrm{mmol})$ and $\mathrm{Ag}_{2} \mathrm{O}(14.8 \mathrm{mg}$, $0.064 \mathrm{mmol})$ were dissolved in dry $\mathrm{CH}_{2} \mathrm{Cl}_{2}(50 \mathrm{~mL})$ and the Schlenk tube was protected from light. The mixture was heated at reflux for $40 \mathrm{~h}$ then filtered through Celite and the solvent was 50 evaporated in vacuo. The residue was purified by column chromatography on neutral alumina (grade I, deactivated with 6$8 \% \mathrm{H}_{2} \mathrm{O}$; eluent: $\mathrm{CH}_{2} \mathrm{Cl}_{2} / \mathrm{MeOH}$ 95:5) to give a deep red solid (74 $\mathrm{mg}, 86 \%$ ). X-Ray quality crystals were obtained by slow diffusion of cyclohexane in a saturated $\mathrm{CH}_{2} \mathrm{Cl}_{2}$ solution. ${ }^{1} \mathrm{H}$ NMR $55\left(400 \mathrm{MHz}, \mathrm{CDCl}_{3}\right) \delta 7.94\left(\mathrm{~d},{ }^{3} J_{\mathrm{HH}}=1.8 \mathrm{~Hz}, 1 \mathrm{H}, H \mathrm{C}=\mathrm{CH} \mathrm{Im}\right)$, $6.83\left(\mathrm{~d},{ }^{3} J_{\mathrm{HH}}=1.8 \mathrm{~Hz}, 1 \mathrm{H}, \mathrm{HC}=\mathrm{C} H \mathrm{Im}\right), 6.82-6.81(\mathrm{~m}, 2 \mathrm{H}$, $\left.\mathrm{C}_{6} \mathrm{H}_{2}\left(\mathrm{CH}_{3}\right)_{3}\right), 5.33\left(\mathrm{dd},{ }^{2} J_{\mathrm{HH}}=14.6 \mathrm{~Hz},{ }^{3} J_{\mathrm{HH}}=3.0 \mathrm{~Hz}, 1 \mathrm{H}\right.$, $\mathrm{CH}_{\mathrm{C}} \mathrm{H}_{\mathrm{D}} \mathrm{Im}$ ), 4.35 (app. s, 6H, 5xC $\left.\mathrm{x}_{5}+\mathrm{C}_{5} \mathrm{H}_{4} \mathrm{~S}\right), 4.26(\mathrm{~m}, 1 \mathrm{H}$, $\left.\mathrm{C}_{5} \mathrm{H}_{4} \mathrm{~S}\right), 4.20\left(\mathrm{~m}, 1 \mathrm{H}, \mathrm{C}_{5} \mathrm{H}_{4} \mathrm{~S}\right), 3.91\left(\mathrm{dd},{ }^{2} J_{\mathrm{HH}}=14.2 \mathrm{~Hz},{ }^{3} J_{\mathrm{HH}}=\right.$ $\left.602.4 \mathrm{~Hz}, 1 \mathrm{H}, \mathrm{CH}_{\mathrm{A}} H_{\mathrm{B}} \mathrm{S}\right), 3.78\left(\mathrm{td},{ }^{2} J_{\mathrm{HH}}={ }^{3} J_{\mathrm{HH}}=14.2 \mathrm{~Hz},{ }^{3} J_{\mathrm{HH}}=3.7\right.$ $\left.\mathrm{Hz}, 1 \mathrm{H}, \mathrm{CH}_{\mathrm{C}} H_{\mathrm{D}} \mathrm{Im}\right), 3.55\left(\mathrm{td},{ }^{2} J_{\mathrm{HH}}={ }^{3} J_{\mathrm{HH}}=13.5 \mathrm{~Hz},{ }^{3} J_{\mathrm{HH}}=4.2\right.$ $\mathrm{Hz}, 1 \mathrm{H}, \mathrm{CH}_{\mathrm{A}} \mathrm{H}_{\mathrm{B}} \mathrm{S}$ ), 3.34 (app. s, $1 \mathrm{H}, \mathrm{C}_{5} H_{4} \mathrm{~S}$ ), 2.29 (s, 3H, $\left.\mathrm{C}_{6} \mathrm{H}_{2}\left(\mathrm{CH}_{3}\right)_{3}\right), \quad 1.98 \quad\left(\mathrm{~s}, \quad 3 \mathrm{H}, \quad \mathrm{C}_{6} \mathrm{H}_{2}\left(\mathrm{CH}_{3}\right)_{3}\right), \quad 1.76 \quad(\mathrm{~s}, \quad 3 \mathrm{H}$, $\left.\mathrm{C}_{6} \mathrm{H}_{2}\left(\mathrm{CH}_{3}\right)_{3}\right), 1.63\left(\mathrm{~s}, 15 \mathrm{H}, \mathrm{C}_{5}\left(\mathrm{CH}_{3}\right)_{5}\right) .{ }^{13} \mathrm{C} \mathrm{NMR}(100 \mathrm{~Hz}$, $\left.{ }_{65} \mathrm{CDCl}_{3}\right) \delta 166.29\left(\mathrm{~d}, \mathrm{~J}_{\mathrm{CRh}}=54.3 \mathrm{~Hz}, \mathrm{NCN}\right), 139.10,138.61$,
135.44, $133.57\left(4 \mathrm{x} \mathrm{C}_{\text {quat }} C_{6} \mathrm{H}_{2}\left(\mathrm{CH}_{3}\right)_{3}\right), 129.16,127.32(2 \mathrm{xCH}$ $\left.C_{6} \mathrm{H}_{2}\left(\mathrm{CH}_{3}\right)_{3}\right), 126.08,124.75(2 \mathrm{x} \mathrm{HC}=C \mathrm{H} \mathrm{Im}), 100.03\left(\mathrm{~d}, \mathrm{~J}_{\mathrm{CRh}}=\right.$ $6.2 \mathrm{~Hz},\left(C_{5}\left(\mathrm{CH}_{3}\right)_{5}\right), 80.35\left(\mathrm{C}_{\text {quat }} C_{5} \mathrm{H}_{4} \mathrm{~S}\right), 72.92\left(\mathrm{CH} C_{5} \mathrm{H}_{4} \mathrm{~S}\right)$, $70.21\left(5 \mathrm{xCH} C_{5} \mathrm{H}_{5}\right), 69.87,69.02,66.50\left(3 \mathrm{xCH} C_{5} \mathrm{H}_{4} \mathrm{~S}\right), 50.03$ $70\left(\mathrm{CH}_{2} \mathrm{Im}\right), 35.17\left(\mathrm{CH}_{2} \mathrm{~S}\right), 21.11,20.08,18.74\left(3 \mathrm{xC}_{6} \mathrm{H}_{2}\left(\mathrm{CH}_{3}\right)_{3}\right)$, $9.47\left(\mathrm{C}_{5}\left(\mathrm{CH}_{3}\right)_{5}\right)$. MS $\left(\mathrm{ESI}^{+}\right) \mathrm{m} / z, 703.5\left(\mathrm{M}^{+}-\mathrm{BF}_{4}, 100 \%\right)$. Elem. Anal. $\mathrm{C}_{34} \mathrm{H}_{41} \mathrm{BClF}_{4} \mathrm{FeN}_{2} \mathrm{RhS}$ (790.50): calc. C, 51.61; H, 5.23; N, 3.54; found $\mathrm{C}, 51.51 ; \mathrm{H}, 5.16 ; \mathrm{N}, 3.46$.

Ruthenium complex (5). Imidazolium salt 3b (52.0 mg, 0.1 $75 \mathrm{mmol}),\left[\mathrm{Ru}(p \text {-cymene }) \mathrm{Cl}_{2}\right]_{2}(54.0 \mathrm{mg}, 0.088 \mathrm{mmol})$ and $\mathrm{Ag}_{2} \mathrm{O}$ (13.6 mg, $0.059 \mathrm{mmol})$ were dissolved in dry $\mathrm{CH}_{2} \mathrm{Cl}_{2}(30 \mathrm{~mL})$ and the Schlenk tube was protected from light. The mixture was heated at reflux for $40 \mathrm{~h}$ then filtered through Celite and the solvent was evaporated to ca. $2 \mathrm{~mL}$. Excess hexane was added 80 and the precipitate was filtered through Celite, rinsed with hexane and recovered by dissolving in $\mathrm{CH}_{2} \mathrm{Cl}_{2}$. The solid was further purified by column chromatography on neutral alumina (grade I, deactivated with 6-8\% $\mathrm{H}_{2} \mathrm{O}$; eluent: $\mathrm{CH}_{2} \mathrm{Cl}_{2} / \mathrm{MeOH}$ 95:5) to give an orange solid $(67 \mathrm{mg}, 85 \%)$. X-Ray quality crystals were 85 obtained by layering a saturated $\mathrm{CDCl}_{3}$ solution with methyl tertbutyl ether. ${ }^{1} \mathrm{H}$ NMR $\left(500 \mathrm{MHz}, \mathrm{CDCl}_{3}\right) \delta 7.56$ (br s, $1 \mathrm{H}$, $H \mathrm{C}=\mathrm{CH} \mathrm{Im}), 7.20\left(\right.$ br s, $\left.1 \mathrm{H}, \mathrm{C}_{6} H_{2}\left(\mathrm{CH}_{3}\right)_{3}\right), 7.09($ br s, $1 \mathrm{H}$, $\left.\mathrm{C}_{6} \mathrm{H}_{2}\left(\mathrm{CH}_{3}\right)_{3}\right), 6.84$ (br s, $\left.1 \mathrm{H}, \mathrm{HC}=\mathrm{CH} \mathrm{Im}\right), 5.51,5.07,4.97$ (br s, $3 \times 1 \mathrm{H}, \mathrm{CH}$-cym), $4.87\left(\mathrm{~m}, 1 \mathrm{H}, \mathrm{CH}_{2} \mathrm{Im}\right), 4.70-4.30(\mathrm{~m}, \mathrm{Xx} 1 \mathrm{H}$, ${ }_{90} \mathrm{C}_{5} H_{4}$ ), 4.47 (br s, $5 x 1 \mathrm{H}, \mathrm{C}_{5} H_{5}$ ), 3.71 (br s, $1 \mathrm{H}, \mathrm{CH}$-cym), 2.69 (br s, $1 \mathrm{H},\left(\mathrm{CH}_{3}\right)_{2} \mathrm{CH}$ p-cym), 2.44, 2.20, 1.98 (br s, 3x3H, $\left.\mathrm{C}_{6} \mathrm{H}_{2}\left(\mathrm{CH}_{3}\right)_{3}\right), 1.81$ (br s, $3 \mathrm{H}, \mathrm{CH}_{3} p$-cym), 1.23, 0.95 (br s, $2 \times 3 \mathrm{H}$, $\left(\mathrm{CH}_{3}\right)_{2} \mathrm{CH} p$-cym). ${ }^{13} \mathrm{C}$ NMR $\left(125.8 \mathrm{MHz}, \mathrm{CDCl}_{3}\right) \delta 164.53$ $(\mathrm{NCN}), 141.02,137.90,137.45,135.45\left(4 \mathrm{x} \mathrm{C}\right.$ quat $\left.C_{6} \mathrm{H}_{2}\left(\mathrm{CH}_{3}\right)_{3}\right)$, $95129.74,129.67\left(2 \times C H C_{6} \mathrm{H}_{2}\left(\mathrm{CH}_{3}\right)_{3}\right), 126.63,122.67(2 \mathrm{x} \mathrm{HC}=C \mathrm{H}$ $\mathrm{Im}), 107.77,103.52\left(2 \mathrm{xC}_{\text {quat }} p\right.$-cym $), 97.68,93.16,88.51,79.78$ (4xCH p-cym), $71.08\left(C_{5} \mathrm{H}_{5}\right), 71.5-68.0\left(C_{5} \mathrm{H}_{4}\right), 49.20\left(C_{2} \mathrm{Im}\right)$, $33.69\left(\mathrm{CH}_{2} \mathrm{~S}\right), 29.51\left(\left(\mathrm{CH}_{3}\right)_{2} \mathrm{CH} p\right.$-cym $), 24.77\left(\left(\mathrm{CH}_{3}\right)_{2} \mathrm{CH} p\right.$ cym $), 21.53\left(\mathrm{C}_{6} \mathrm{H}_{2}\left(\mathrm{CH}_{3}\right)_{3}\right), 20.41\left(\left(\mathrm{CH}_{3}\right)_{2} \mathrm{CH} p\right.$-cym $), 18.63$, $10018.62\left(\mathrm{C}_{6} \mathrm{H}_{2}\left(\mathrm{CH}_{3}\right)_{3}\right), 17.95\left(\mathrm{CH}_{3} p\right.$-cym). MS $\left(\mathrm{ESI}^{+}\right) \mathrm{m} / z, 701\left(\mathrm{M}^{+}-\right.$ $\left.\mathrm{BF}_{4}, 100 \%\right)$.

X-ray crystallography. A single crystal of each compound was mounted under inert perfluoropolyether at the tip of a cryoloop and cooled in the cryostream of an Agilent Technologies OD 105 XCALIBUR 3 CCD diffractometer for $\mathbf{4}$ or a GEMINI EOS CCD diffractometer for 5. Data were collected using the monochromatic MoK $\alpha$ radiation $(\lambda=0.71073)$. The structures were solved by direct methods (SIR97) ${ }^{27}$ and refined by leastsquares procedures on $F^{2}$ using SHELXL-97. ${ }^{28}$ All $\mathrm{H}$ atoms 110 attached to carbon were introduced in idealised positions and treated as riding on their parent atoms in the calculations. In compound 4 , the $\mathrm{BF}_{4}$ was found to be disordered, and three orientations of ca. 81,10 and $9 \%$ occupancy were identified. The geometries of all three orientations were optimised, the thermal 115 parameters of adjacent equivalent atoms were restrained to be similar, and only the non-hydrogen atoms of the major occupancy orientation were refined anisotropically (the others were refined isotropically). The drawing of the molecules was realised with the help of ORTEP $3 .^{29}$ Crystal data and refinement parameters: see 120 footntotes. Selected bond distances and angles are given in Table 1. Crystallographic data (excluding structure factors) have been deposited with the Cambridge Crystallographic Data Centre as supplementary publication no. CCDC 816175-816176. Copies of the data can be obtained free of charge on application to the 125 Director, CCDC, 12 Union Road, Cambridge CB2 1EZ, UK (fax: (+44) 1223-336-033; e-mail: deposit@ ccdc.cam.ac.uk). 


\section{Notes and references}

${ }^{a}$ CNRS ; LCC (Laboratoire de Chimie de Coordination) ; 205, route de Narbonne, F-31077 Toulouse, France, and Université de Toulouse ; UPS, INPT ; LCC ; F-31077 Toulouse, France. Fax: +33 561553003; Tel: +33 5 561333158; E-mail: agnes.labande@ @ $\odot$ lcc-toulouse.fr, corresponding author.

${ }^{b}$ Department of Chemistry, Imperial College London, London, SW7 2AZ, United Kingdom. Fax: +44 2075945804; Tel: +44 2075945781; E-mail: n.long@imperial.ac.uk.

$10^{c}$ Institut Universitaire de France, 103, bd Saint-Michel, 75005 Paris, France.

$\dagger$ Electronic Supplementary Information (ESI) available: Square-wave voltammogram of complex $\mathbf{5}$, crystal data and structure refinement and selected bonds and angles for complexes $\mathbf{4}$ and $\mathbf{5}$. See 15 DOI: $10.1039 / \mathrm{b} 000000 \mathrm{x} /$

\$ Crystal data for 4: $\left[\mathrm{C}_{34} \mathrm{H}_{41} \mathrm{ClFeN}_{2} \mathrm{RhS}\right]\left(\mathrm{BF}_{4}\right) \cdot \mathrm{CH}_{2} \mathrm{Cl}_{2}, \mathrm{M}=875.69$, triclinic, $P \overline{1}$ (no. 2), a = 10.6786(2), $\mathrm{b}=11.8064(3), \mathrm{c}=15.8586(3) \AA, \alpha$ $=96.8086(18), \beta=102.4583(19), \gamma=106.009(2)^{\circ}, V=1842.52(7) \AA^{3}, Z$ $=2, \mathrm{D}_{\mathrm{c}}=1.578 \mathrm{~g} \mathrm{~cm}^{-3}, \mu(\mathrm{Mo}-\mathrm{K} \alpha)=1.164 \mathrm{~mm}^{-1}, \mathrm{~T}=173 \mathrm{~K}$, orange 20 tablets, Oxford Diffraction Xcalibur 3 diffractometer; 12107 independent measured reflections $\left(\mathrm{R}_{\text {int }}=0.0239\right), \mathrm{F}^{2}$ refinement, $\mathrm{R}_{1}(\mathrm{obs})=0.0331$, $\mathrm{wR}_{2}(\mathrm{all})=0.0856,10327$ independent observed absorption-corrected reflections $\left[\left|\mathrm{F}_{\mathrm{o}}\right|>4 \sigma\left(\left|\mathrm{F}_{\mathrm{o}}\right|\right), 2 \theta_{\max }=66^{\circ}\right], 484$ parameters. CCDC 816175 . Crystal data for 5: $\left[\mathrm{C}_{34} \mathrm{H}_{40} \mathrm{ClFeN}_{2} \mathrm{RuS}\right]\left(\mathrm{BF}_{4}\right) \cdot \mathrm{CH}_{2} \mathrm{Cl}_{2}, M=787.92$, 25 monoclinic, $P 2_{1} / \mathrm{n}$ (no. 14), $a=11.8820(3), b=10.2423(2), c=$ 27.5100(7) $\AA, \beta=94.493(2), V=3337.65(14) \AA^{3}, Z=4, D_{\mathrm{c}}=1.568 \mathrm{~g} \mathrm{~cm}^{-}$ ${ }^{3}, \mu(\mathrm{Mo}-\mathrm{K} \alpha)=1.080 \mathrm{~mm}^{-1}, T=180 \mathrm{~K}$, orange tablets, Oxford Diffraction Gemini Eos diffractometer; 7574 independent measured reflections $\left(R_{\text {int }}=\right.$ $0.063), F^{2}$ refinement, $R_{1}(\mathrm{obs})=0.0512, w R_{2}($ all $)=0.1073,5590$ 30 independent observed absorption-corrected reflections $\left[\left|F_{\mathrm{o}}\right|>4 \sigma\left(\left|F_{\mathrm{o}}\right|\right)\right.$, $2 \theta_{\max }=55^{\circ}$ ], 412 parameters. CCDC 816176 .

1 For selected books and recent reviews, see: S. Díez-González, $N$ Heterocyclic Carbenes: From Laboratory Curiosities to Efficient Synthetic Tools, RSC Publishing, Cambridge, UK, 2011 ; F.Glorius, $N$-Heterocyclic Carbenes in Transition Metal Catalysis, SpringerVerlag, Heidelberg, Germany, 2007; V. César, S. BelleminLaponnaz and L. H. Gade, Chem. Soc. Rev., 2004, 33, 619; F. E. Hahn and M. C. Jahnke, Angew. Chem. Int. Ed. 2008, 47, 3122 ; S. Díez-González, N. Marion and S. P. Nolan, Chem. Rev., 2009, 109,

$40 \quad 3612$; J. C. Y. Lin, R. T. W. Huang, C. S. Lee, A. Bhattacharyya, W. S. Hwang and I. J. B. Lin, Chem. Rev., 2009, 109, 3561; P. L. Arnold and I. J. Casely, Chem. Rev., 2009, 109, 3599.

2 For selected reviews, see: D. Enders, O. Niemeier and A. Henseler, Chem. Rev., 2007, 107, 5606 ; N. Marion, S. Díez-González and S. P.

45 Nolan, Angew. Chem. Int. Ed. 2007, 46, 2988.

3 G. Gasser, I. Ott and N. Metzler-Nolte, J. Med. Chem., 2011, 54, 3 ; A. Kascatan-Nebioglu, M. J. Panzner, C. A. Tessier, C. L. Cannon and W. J. Youngs, Coord. Chem. Rev., 2007, 251, 884.

4 H. M. Lee, C. C. Lee and P. Y. Cheng, Curr. Org. Chem., 2007, 11,

501491 ; O. Kuhl, Chem. Soc. Rev., 2007, 36, 592; A. T. Normand and K. J. Cavell, Eur. J. Inorg. Chem., 2008, 2781; A. John and P. Ghosh, Dalton Trans., 2010, 39, 7183.

5 Selected papers on S-NHC ligands: M. Bierenstiel, E. D. Cross, Coord. Chem. Rev., 2011, 255, 574 and references therein ; C. Fliedel and P. Braunstein, Organometallics, 2010, 29, 5614 ; C. Fliedel, A. Sabbatini and P. Braunstein, Dalton Trans., 2010, 39, 8820; C. Fliedel, G. Schnee and P. Braunstein, Dalton Trans., 2009, 2474 ; A. Ros, M. Alcarazo, D. Monge, E. Álvarez, R. Fernández and J. M. Lassaletta, Tetrahedron: Asymmetry, 2010, 21, 1557 ; S. J.

60 Roseblade, A. Ros, D. Monge, M. Alcarazo, E. Alvarez, J. M. Lassaletta and R. Fernandez, Organometallics, 2007, 26, 2570 ; A. Ros, D. Monge, M. Alcarazo, E. Alvarez, J. M. Lassaletta and R. Fernandez, Organometallics, 2006, 25, 6039 ; H. V. Huynh, D. Yuan and Y. Han, Dalton Trans., 2009, 7262 ; H. V. Huynh, C. H. Yeo and G. K. Tan, Chem. Commun., 2006, 3833.

6 C. Gandolfi, M. Heckenroth, A. Neels, G. Laurenczy and M. Albrecht, Organometallics, 2009, 28, 5112.

7 For ferrocene-containing NHC ligands, see: B. Bildstein, M. Malaun, H. Kopacka, K.-H. Ongania and K. Wurst, J. Ogranomet. Chem., 70 1998, 552, 45; H. Seo, H.-J. Park, B. Y. Kim, J. H. Lee, S. U. Son and Y. K. Chung, Organometallics, 2003, 22, 618 ; K. S. Coleman, S. Gischig and A. Togni, Organometallics, 2004, 23, 2479; S. Turberville, S. I. Pascu and M. L. H. Green, J. Organomet. Chem., 2005, 690, 653; D. M. Khramov, E. L. Rosen, V. M. Lynch and C. W. Bielawski, Angew. Chem. Int. Ed., 2008, 47, 2267; E. L. Rosen, C. D. Varnado, A. G. Tennyson, D. M. Khramov, J. W. Kamplain, D. H. Sung, P. T. Cresswell, V. M. Lynch and C. W. Bielawski, Organometallics, 2009, 28, 6695 ; C. D. Varnado Jr, V. M. Lynch and C. W. Bielawski, Dalton Transactions, 2009, 7253; U. Siemeling, C. Färber and C. Bruhn, Chem. Commun., 2009, 98.

8 P. D. Beer, P. A. Gale, Z. Chen, Adv. Phys. Org. Chem., 1999, 31, 1; A. Niemz and V. M. Rotello, Acc. Chem. Res., 1998, 32, 44.

9 For selected papers, see: C. Valério, J.-L. Fillaut, J. Ruiz, J. Guittard, J.-C. Blais and D. Astruc, J. Am. Chem. Soc., 1997, 119, 2588 ; A.

85 Labande, J. Ruiz and D. Astruc, J. Am. Chem. Soc., 2002, 124, 1782 ; D. Astruc, C. Ornelas and J. Ruiz, Acc. Chem. Res., 2008, 41, 841 ; D. Astruc, E. Boisselier and C. Ornelas, Chem. Rev., 2010, 110, 1857.

10 A. M. Allgeier and C. A. Mirkin, Angew. Chem. Int. Ed., 1998, 37, 90894 ; G. Liu, H. He and J. Wang, Adv. Synth. Catal., 2009, 351, 1610.

11 I. M. Lorkovic, R. R. Duff Jr. and M. S. Wrighton, J. Am. Chem. Soc., 1995, 117, 3617 ; C. K. A. Gregson, V. C. Gibson, N. J. Long, E. L. Marshall, P. J. Oxford and A. J. P. White, J. Am. Chem. Soc., 2006, 128, 7410 ; M. D. Sanderson, J. W. Kamplain and C. W. Bielawski, J. Am. Chem. Soc., 2006, 128, 16514 ; A. B. Powell, C. W. Bielawski and A. H. Cowley, J. Am. Chem. Soc., 2009, 131, 18232 ; A. G. Tennyson, V. M. Lynch and C. W. Bielawski, J. Am. Chem. Soc., 2010, 132, 9420; A. B. Powell, C. W. Bielawski and A. 100 H. Cowley, J. Am. Chem. Soc., 2010, 132, 10184 ; A. G. Tennyson, R. J. Ono, T. W. Hudnall, D. M. Khramov, J. A. V. Er, J. W. Kamplain, V. M. Lynch, J. L. Sessler and C. W. Bielawski, Chem. Eur. J., 2010, 16, 304.

12 T. B. Higgins and C. A. Mirkin, Inorg. Chim. Acta, 1995, 240, 347 ; 105 E. T. Singewald, X. Shi, C. A. Mirkin, S. J. Schofer and C. L. Stern, Organometallics, 1996, 15, 3062 ; A. M. Allgeier and C. A. Mirkin, Organometallics, 1997, 16, 3071 ; C. S. Slone, C. A. Mirkin, G. P. A. Yap, I. A. Guzei and A. L. Rheingold, J. Am. Chem. Soc., 1997, 119, 10743 ; X. Liu, A. H. Eisenberg, C. L. Stern and C. A. Mirkin, Inorg. Chem., 2001, 40, 2940 ; D. A. Weinberger, T. B. Higgins, C. A. Mirkin, C. L. Stern, L. M. Liable-Sands and A. L. Rheingold, J. Am. Chem. Soc., 2001, 123, 2503.

13 J. Wolf, A. Labande, J.-C. Daran and R. Poli, Eur. J. Inorg. Chem., 2007, 5069.

11514 S. Gülcemal, A. Labande, J.-C. Daran, B. Çetinkaya and R. Poli, Eur. J. Inorg. Chem., 2009, 1806 ; N. Debono, A. Labande, E. Manoury, J.-C. Daran and R. Poli, Organometallics, 2010, 29, 1879.

15 I. V. Kourkine, C. S. Slone, E. T. Singewald, C. A. Mirkin, L. M. Liable-Sands and A. L. Rheingold, Inorg. Chem., 1999, 38, 2758.

12016 A. M. Allgeier, C. S. Slone, C. A. Mirkin, L. M. Liable-Sands, G. P. A. Yap and A. L. Rheingold, J. Am. Chem. Soc., 1997, 119, 550.

17 J. A. Mata, A. R. Chianese, J. R. Miecznikowski, M. Poyatos, E. Peris, J. W. Faller and R. H. Crabtree, Organometallics, 2004, 23, 1253.

12518 S. Saravanakumar, M. K. Kindermann, J. Heinicke and M. Koeckerling, Chem. Commun., 2006, 640; D. M. Khramov, V. M. Lynch and C. W. Bielawski, Organometallics, 2007, 26, 6042 ; D. Tapu, C. Owens, D. VanDerveer and K. Gwaltney, Organometallics, 2009, 28, 270.

13019 A. Kascatan-Nebioglu, M. J. Panzner, J. C. Garrison, C. A. Tessier and W. J. Youngs, Organometallics, 2004, 23, 1928.

20 A. P. da Costa, M. Sanaú, E. Peris and B. Royo, Dalton Trans., 2009, 6960 ; K. Ogata, T. Nagaya, S.-i. Fukuzawa, J. Organomet. Chem., 2010, 695, 1675.

13521 M. Poyatos, A. Maisse-François, S. Bellemin-Laponnaz, E. Peris and L. H. Gade, J. Organomet. Chem., 2006, 691, 2713; R. Cariou, C. Fischmeister, L. Toupet and P. H. Dixneuf, Organometallics, 2006, 25, 2126; X. Wang, S. Liu, L.-H. Weng and G.-X. Jin, Chem. Eur. J., 2007, 13, 188; Y. Zhang, C. Chen, S. C. Ghosh, Y. Li and S. H. 140 Hong, Organometallics, 2010, 29, 1374; W. Ghattas, H. Müller-Bunz 
and M. Albrecht, Organometallics, 2010, 29, 6782; Wylie W. N. O, A. J. Lough and R. H. Morris, Organometallics, 2011, 30, 1236.

22 F.H. Allen, Acta Crystallogr., Sect. B: Struct. Sci., 2002, B58, 380.

23 For a comprehensive review on chemical redox agents, see: N. G. Connelly and W. E. Geiger, Chem. Rev., 1996, 96, 877.

24 The weak feature at $0.1 \mathrm{~V}$ is probably due to traces of oxygen. A second experiment carried out on the same sample in the range $-1 \mathrm{~V} /+1.2 \mathrm{~V}$ showed no such feature but only the ferrocene/ferrocenium redox wave.

1025 T. Sixt, M. Sieger, M. J. Krafft, D. Bubrin, J. Fiedler and W. Kaim, Organometallics, 2010, 29, 5511.

26 A. G. Tennyson, D. M. Khramov, C. D. Varnado, P. T. Creswell, J. W. Kamplain, V. M. Lynch and C. W. Bielawski, Organometallics, 2009, 28, 5142.

1527 A. Altomare, M. C. Burla, M. Camalli, G. L. Cascarano, C. Giacovazzo, A. Guagliardi, A. G. G. Moliterni, G. Polidori and R. Spagna, J. Appl. Crystallogr., 1999, 32, 115.

28 G. M. Sheldrick, Acta Crystallogr., Sect. A: Found. Crystallogr., 2008, A64, 112.

2029 M. N. Burnett and C. K. Johnson, ORTEPIII, Report ORNL-6895, Oak Ridge National Laboratory, Oak Ridge, Tennessee, U.S, 1996; L. J. Farrugia, J. Appl. Crystallogr., 1997, 30, 565. 